\title{
Prudent Use of Antimicrobials in Exotic Animal Medicine
}

\author{
Els M. Broens, PhD, DVMa \\ Ingeborg M. van Geijlswijk, PhD, PharmD ${ }^{\text {, * }}$
}

\section{KEYWORDS}

\author{
- Antimicrobial stewardship • Use • Resistance • Monitoring • Policy
}

\section{KEY POINTS}

- Awareness starts with monitoring: knowing what resistant bacteria are emerging in patients and the environment and which and how frequently antimicrobials are being prescribed and used by veterinarians in specified animal species.

- The next step is to choose effective therapy strategies of active substances, doses, and duration that result in minimal selection of resistance.

- The recognition of the nonrenewable nature of the available antimicrobials in animal medicine stimulates the prudent use of antimicrobial medicines.

- Antimicrobial stewardship consists of a coherent set of actions that promote prudent use of antimicrobials with an emphasis on societal responsibility.

\section{INTRODUCTION}

Antimicrobial use (AMU) in veterinary medicine is considered a potential threat for public health. Overuse and misuse of antimicrobials in animals and humans are contributing to the rising threat of antimicrobial resistance (AMR). AMR is the ability of microorganisms, such as bacteria, to become increasingly resistant to an antimicrobial to which they were previously susceptible. Any use of antimicrobials favors the survival and spread of resistant bacteria or genes. This selection pressure applies to pathogenic bacteria, but also to commensal bacteria (eg, gut flora). Longer treatments automatically result in more selection of AMR, underdosing or poor client compliance results in therapy failure and therefore futile application of antimicrobials. Over time, this makes antimicrobials less effective and ultimately useless. To reduce

The authors have nothing to disclose.

a Department of Infectious Diseases and Immunology, Clinical Infectiology, Utrecht University, Yalelaan 106, Utrecht 3584 CM, The Netherlands; ${ }^{b}$ IRAS Veterinary Pharmacology and Therapeutics Group, Pharmacy Department, Utrecht University, Yalelaan 106, Utrecht 3584 CM, The Netherlands

* Corresponding author.

E-mail address: I.M.vanGeijlswijk@uu.nl 
the burden of AMR, prudent use of antimicrobials should be promoted. In 2015, the World Health Organization (WHO) endorsed a global action plan to tackle $\mathrm{AMR}^{1}$ and recently it recommended banning the prophylactic use of antimicrobials in healthy animals. ${ }^{2}$ The WHO also compiled a list of critically important antimicrobials for human medicine for risk management of AMR because of nonhuman use (Table 1).

Most action plans are primarily focusing on AMU in food-producing animals, but recommendations are also applicable for other animal species, including exotic animals. In response to publications from WHO, the European Commission (making the European Union a best practice region ${ }^{3}$ ), other international organizations, and several national and international veterinary associations have developed recommendations and policies on prudent use of antimicrobials, not only for food-producing animals, but also for companion animals ${ }^{4}$ and horses. ${ }^{5}$ In exotic animals, such recommendations and policies seem to be lacking. A search on Web sites of various exotic animal-related veterinary associations (eg, Association of Exotic Mammal Veterinarians [AEMV], European College of Zoological Medicine [ECZM], European Association of Zoo and Wildlife Veterinarians [EAZWV]) revealed no documents on prudent use of antimicrobials. Evaluation of overuse or misuse in exotic animals is hard because little to no information is available on AMU and AMR in these animals. In general, it seems that there is plenty of room for improvement in AMU and AMR in exotic animal medicine. This article discusses different actions in veterinary medicine on prudent AMU, and addresses the applicability of these actions in exotic animal medicine.

\section{MONITORING OF ANTIMICROBIAL USE}

Any plan to promote prudent use has to start with monitoring AMU: the numbers tell the tale. Implementation of monitoring programs is crucial to reduce AMU and AMR. National programs monitoring AMU and AMR in animals have been established in several

\begin{tabular}{|ll}
\hline \multicolumn{2}{l}{ Table 1} \\
List and classification of antimicrobials important for human & medicine \\
\hline Antimicrobial Class & Example of Drugs \\
\hline Aminoglycosides & Gentamicin \\
\hline Ansamycins & Rifampicin \\
\hline Carbapenems and other penems & Meropenem \\
\hline Cephalosporins (third, fourth, and fifth generation) & Ceftazidime, cefepime \\
\hline Glycopeptides & Vancomycin \\
\hline Glycylcyclines & Tigecycline \\
\hline Lipopeptides & Daptomycin \\
\hline Macrolides and ketolides & Erythromycin, azithromycin \\
\hline Monobactams & Aztreonam \\
\hline Oxazolidinones & Linezolid \\
\hline Penicillins (natural, aminopenicillins, and antipseudomonal) & Ampicillin \\
\hline Phosphonic acid derivatives & Fosfomycin \\
\hline Polymyxins & Colistin \\
\hline Quinolones & Ciprofloxacin \\
\hline Drugs used solely to treat tuberculosis or other mycobacterial & Isoniazid \\
\hline diseases & \\
\hline
\end{tabular}

Data from World Health Organization. Critically important antimicrobials for human medicine. 5th revision. 2017. Available at: http://www.who.int/foodsafety/publications/antimicrobials-fifth/en/. Accessed December 17, 2017. 
countries (eg, DANMAP, ${ }^{6}$ SWEDRES, ${ }^{7}$ MARAN,${ }^{8}$ AMCRA $^{9}$ ). The methodologies among countries might differ, making direct comparisons or conclusions difficult. ${ }^{10,11}$ Most monitoring programs are based on the total mass of active substances sold per year. However, the comparison of use in mass neglects the dosing differences between different antimicrobial agents, dosing regimens, and animal species.

The European Medicines Agency started the European Surveillance of Veterinary Antimicrobial Consumption (ESVAC) project in 2010 to harmonize data collection and analysis methodologies for AMU across the European Union. ESVAC has established standardized ways to calculate the animal population (ie, population correction unit). ${ }^{12,13}$ This methodology is mainly based on production parameters and therefore needs additional refinement for application in non-food-producing animals. Ideally, calculation of the potentially exposed population of companion animals, such as exotics, should mimic the method applied in human AMU calculations (eg, by the European Surveillance of Antimicrobial Consumption ${ }^{14}$ ). This requires that the number of animals is known, so some kind of registration of animals is needed. In the Netherlands this method was applied for measuring AMU in dogs, cats, and rabbits, ${ }^{15}$ which also showed the limitations of this system when an official registration of number of animals is missing, and no standard weight (like in humans) is available.

ESVAC has also established standardized units of measurement for reporting antimicrobial consumption in specific animal species, called the defined daily dose. ${ }^{16}$ The defined daily dose will enable a better analysis over time and a comparison among species at the European level in time, but currently animal species specified sales data are available for only a few countries on a national level, because the attribution to species level of sales data is not possible within the current data collection system. Most of the monitoring programs focus on AMU in livestock; data on AMU in companion animals (eg, dogs, cats, horses, and rabbits) are scarce and data specifically on exotic animals are absent.

The seventh ESVAC report presents data on the sales of veterinary antimicrobial agents from 30 European countries in 2015 and trends in consumption of veterinary antimicrobials for the years 2010 to $2015 .{ }^{17}$ In this report, the sales of tablets, in tons of active ingredient, by antimicrobial class and country, was used to estimate AMU in companion animals. The data might be slightly biased, because the assumption was that tablets are used almost solely for companion animals and tablets marketed for human use and injectables were not included. Especially in minor species, such as exotic animals, the use of human or injectable products might be high compared with its use in dogs and cats. In Europe, aminopenicillins combined with $\beta$-lactamase inhibitors (mainly amoxicillin/clavulanic acid) and first- and secondgeneration cephalosporins (mainly cephalexin) account for $65 \%$ of the total mass of active substance of sold antimicrobial tablets for companion animals. In some countries, fluoroquinolones represent more than $50 \%$ of the active substance mass in tablets. ${ }^{17}$ The comparison of use in mass neglects the dosing differences between antimicrobials. For example, fluoroquinolones $(2-6 \mathrm{mg} / \mathrm{kg} / \mathrm{d}$ ) require lower dosing in comparison with aminopenicillins $(25-50 \mathrm{mg} / \mathrm{kg} / \mathrm{d})$, which implies that $50 \%$ in mass means that far more than $50 \%$ of the oral treatments consist of treatment with fluoroquinolones.

In the United States pharmaceutical companies selling veterinary antimicrobial products (called antimicrobial drug sponsors) are obliged by Section 105 of the Animal Drug User Fee Amendments of 2008 to report their sales data of all veterinary antimicrobial products to the US Food and Drug Authority. Starting with calendar year 2016, additionally species-specific sales estimates as a percentage of total domestic sales and distribution for each product was required. Of the 2016 sales, $4 \%$ was reported 
intended for use in species other than cattle, swine, chickens, and turkeys or unknown uses. The report does not specify this "other use" further. ${ }^{18}$

The Netherlands Veterinary Medicines Institute (SDa) has been monitoring the amounts of antibiotics used at Dutch livestock farms since 2011. After rigorous measures taken in livestock during 2009 to 2016 resulting in a $60 \%$ reduction of use, monitoring of AMU was extended to companion animals. ${ }^{19}$ In 2016 , a survey was performed by the SDa to assess AMU in companion animals (dogs, cats, and rabbits). The survey, which included data from $10 \%$ of Dutch veterinary practices, revealed a large variation in AMU between practices, but overall usage levels were low. Results showed that amoxicillin (either alone or combined with a $\beta$-lactamase inhibitor) and firstgeneration cephalosporins accounted for $51 \%$ of the treatment days in 2012 , and fluoroquinolones and third-generation cephalosporins for $21 \%$. In 2014 , these numbers were, respectively, 51\% and 6.9\%. ${ }^{15}$ In Australia in 2011, treatment incidences were estimated with a questionnaire, and overall, the most common antimicrobial classes were potentiated aminopenicillins (36\%), fluoroquinolones (15\%), first- and secondgeneration cephalosporins (14\%), and tetracyclines (11\%). In cats, third-generation cephalosporins were overrepresented. ${ }^{20}$ In New Zealand, Canada, and the United Kingdom similar figures were found. ${ }^{21-23}$ These figures indicate that fluoroquinolones, potentiated aminopenicillins, and cephalosporins are among the most used antimicrobial agents in companion animals, despite it being common knowledge that these agents select for multidrug resistant bacteria (eg, methicillin-resistant staphylococci and extended-spectrum $\beta$-lactamase-producing Enterobacteriaceae). ${ }^{24}$

The only published data on AMU in exotic animals came from a study at the Zoologic Medicine Service of the Veterinary Teaching Hospital at the University of Georgia. Although this study did not provide information on the amount or type of antimicrobials used, it did indicate that most antimicrobial prescriptions were unnecessary or inappropriate. ${ }^{25}$ Most antimicrobial prescriptions seemed to be empiric and not based on proper diagnostics. The occurrence of multidrug-resistant bacteria has been reported in several exotic animal species, such as methicillin-resistant staphylococci in birds and rabbits, and extended-spectrum $\beta$-lactamase-producing Enterobacteriaceae in wild birds and turtles. ${ }^{26-30}$

\section{RECOMMENDATIONS AND POLICIES}

Several international and national organizations have developed recommendations and policies to promote prudent use of antimicrobials in veterinary and human medicine. The WHO list of critically important antimicrobials for human medicine contains several antimicrobial classes used in animals. The antimicrobial classes with the highest priority are quinolones, third- and fourth-generation cephalosporins, macrolides, and glycopeptides. ${ }^{31}$ Except for the latter, all classes are authorized in animals, and especially in exotic animals, quinolones and macrolides are used often. The guidelines for the prudent use of antimicrobials in veterinary medicine composed by the European Commission in 2015 state: "The off-label (cascade) use of antimicrobials not authorized in veterinary medicine to treat non-food-producing animals should be avoided, especially when the drugs are of critical importance for human health (eg, carbapenems and tigecycline). Their use should only be considered in very exceptional cases, for example, when laboratory susceptibility testing has confirmed that no other antimicrobials will be effective and where there are ethical reasons to justify such a course of treatment." ${ }^{32}$ In the Netherlands, the use of carbapenems, glycopeptides, oxazolidones, daptomycin, mupirocin, and tigecyclin in animals is prohibited. ${ }^{33}$ The use of fluoroquinolones and third- and fourth-generation cephalosporins is by 
Dutch law restricted to infections caused by bacteria with susceptibility results indicating that all other options are ineffective. ${ }^{34,35}$ In other countries no such legislations are implemented yet, but empiric or prophylactic use of these antimicrobials should be avoided whenever possible.

Although the European Commission guidelines mainly focus on food-producing animals, these also address clinical infections with methicillin-resistant Staphylococcus aureus or methicillin-resistant Staphylococcus pseudintermedius in horses and companion animals. The guidelines state that these infections should be monitored and transmission should be minimized.

In countries where a substantial reduction in AMU was achieved, a decline in AMR in commensal bacteria, such as Escherichia coli, was seen in the following years. ${ }^{36,37}$ The second Joint Interagency Antimicrobial Consumption and Resistance Analysis report of July 2017 confirms the positive association between AMU and AMR in humans and food-producing animals and underlines the need to ensure prudent use of antimicrobials in food-producing animals and humans. ${ }^{14}$ The WHO guidelines on use of medically important antimicrobials in food-producing animals ${ }^{2}$ is based on a meta-analysis by Tang and colleagues ${ }^{38}$ concluding that reduction of AMU in food-producing animals was associated with a reduction in AMR in food-producing animals and in humans in direct contact with these animals. These results provide evidence for an association between reduction of AMU and reduction of AMR and confirm that prudent use of antimicrobials should be promoted or even enforced in veterinary (and human) medicine.

\section{ANTIMICROBIAL STEWARDSHIP}

In human medicine, the term antimicrobial stewardship was introduced a few decades ago and describes the multifaceted approach considering the long-term effects of antimicrobial selection, dosage, and duration of treatment on resistance development. ${ }^{39}$ Antimicrobial stewardship focuses on the reduction of resistance selection and the preservation of effective antimicrobials for future generations. It consists of a coherent set of actions that promote responsible use of antimicrobials with an emphasis on the societal responsibility. ${ }^{40}$ During the 1990 s and 2000 s antimicrobial stewardship programs were implemented in human hospitals in many countries. The primary goal of these programs was to optimize clinical outcomes while minimizing unintended consequences of $A M U$, including toxicity, the selection of pathogenic organisms, and the emergence of resistance. Antimicrobial stewardship involves coordinated approaches and interventions; it is not only about reducing AMU, but also about infection control, clinical microbiology, surveillance of AMU and AMR, education, guidelines, and regulations. Nowadays, antimicrobial stewardship programs are up and running in most human hospitals. Multidisciplinary teams are formed, the so-called A(ntibiotic) teams, monitoring all aspects of AMU and AMR, including the implementation of and compliance with guidelines.

Most veterinarians are aware of AMR, but antimicrobial stewardship is new to veterinary medicine. Few papers have been published on veterinary antimicrobial stewardship, mainly focusing on companion animals ${ }^{4}$ and horses. ${ }^{5}$ National organizations of veterinarians (eg, Royal Netherlands Veterinary Association [RNVA], British Small Animal Veterinary Association [BSAVA]), and international organizations specialized in companion animals (Federation of Companion Animal Veterinary Associations [FECAVA]) and horses (British Equine Veterinary Association [BEVA]) initiated programs to stimulate awareness and provide guidelines for veterinarians and pet owners. $A$ recent paper provides an overview on antimicrobial stewardship in laboratory animals, 
mainly focusing on rodents and rabbits. ${ }^{41}$ Experts in veterinary antimicrobial stewardship suggest to add two Rs to the well-known three Rs frequently used in laboratory animals. Antimicrobial stewardship not only requires reduction, refinement, and replacement, but also responsibility and review. ${ }^{42}$ The establishment of an antimicrobial stewardship program in a veterinary hospital or clinic requires a comprehensive list of components, such as knowledge, guidelines, surveillance, diagnostic tools, collaboration, commitment, finances, and willingness of all involved parties including the pet owner. Considering all these components, one might be discouraged before even starting. However, not all components have to be in place at the start of implementing an antimicrobial stewardship program. Every clinic can start with minor steps, such as responsibility by awareness and recognition of the problem, reduction by shortening the duration of antimicrobial therapy, refinement by using narrow-spectrum antimicrobials when possible, replacement by introducing alternative (nonantimicrobial) treatment when available, and review by implementation of therapy evaluation.

\section{CHALLENGES FOR RESPONSIBLE ANTIMICROBIAL USE IN EXOTIC ANIMALS}

Data estimating AMU and AMR in exotic animals are lacking. The options in available antimicrobials for the different exotic animal species are often limited. Potentially toxic or adverse effects of some antimicrobials in specific animal species and the formulation make the range of available products even smaller.

In exotic animals, several challenges complicate antimicrobial treatment, and may result in practical arguments to choose certain veterinary medicinal products or products authorized for human use, compromising the choice for the right antimicrobial drug in this patient at this time. Challenges comprise the right formulation (liquids are preferred over tablets), the right concentration, and the acceptance of the animal (taste). In veterinary practice this means that in birds liquid oral forms of aminopenicillins for human use are attractive, because these substances are dosed much higher in most birds, so even doses for a small exotic animal are measurable, and the liquid has an acceptable taste for most birds. The same arguments are applicable for azithromycin, of which the liquid formula authorized for human use is convenient for dosing in small birds and rodents. ${ }^{43}$ In rabbits, guinea pigs, and other herbivorous rodents, antimicrobial treatment options are limited because oral treatment with several antimicrobial agents (ie, penicillin, lincomycin, amoxicillin, ampicillin, cephalosporins, clindamycin, erythromycin, streptomycin) may result in dysbiosis and enterotoxaemia. This results in generic advices comprising fluoroquinolones, such as respiratory infections and abscesses of odontogenic origin. ${ }^{44,45}$ In reptiles, infections are often associated with Pseudomonas spp, resulting in the application of ceftazidime. Although ceftazidime has great antipseudomonal activity, it is a third-generation cephalosporin authorized for human use only, and classified as highest priority critically important for human medicine. ${ }^{31}$

Another challenge is the availability of literature concerning the dosing of antibiotics in exotics. Controversially, more dosing information is available about newer antimicrobial substances, such as fluoroquinolones. ${ }^{46-48}$ As a result, in the Netherlands, four enrofloxacin-containing veterinary medicinal products are authorized for exotic animals including rodents, in addition to two trimethoprim/sulfonamide-containing drugs. No other antimicrobial products are authorized, making off-label use common practice in exotic animal medicine.

In addition, information on common bacterial pathogens to be encountered in specific locations in the different species is not always readily available. Without this knowledge, choosing the right antimicrobial drug becomes more difficult, thereby 
rendering it more likely for the veterinarian to make decisions based on empiric evidence and pragmatic arguments.

\section{GUIDELINES FOR RESPONSIBLE ANTIMICROBIAL USE IN EXOTICS}

Several factors should be considered when prescribing and selecting an antimicrobial agent (Fig. 1). First, antimicrobials should only be used when a primary bacterial infection or secondary bacterial involvement is proven or highly likely. If other, nonbacterial causes (eg, parasitic, viral, or mycotic infection, noninfectious disease) are more likely, diagnosis and treatment should primarily focus on those causes. The need for AMU to prevent infection is debatable, and should be reserved for those cases where occurrence of an infection is likely to occur and result in life-threatening disease (eg, sepsis in severely immunocompromised patients). Other considerations that should be taken
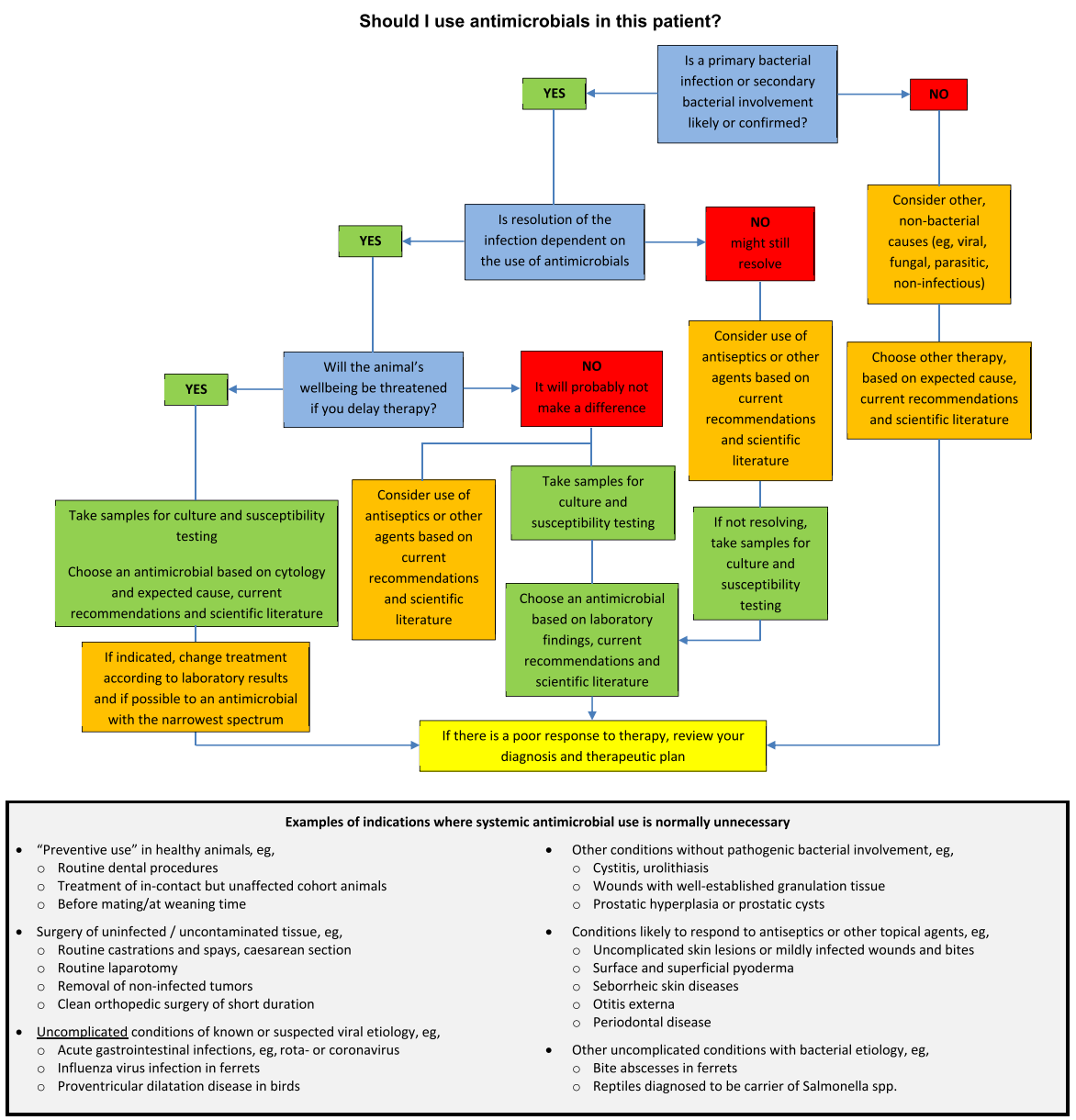

Fig. 1. Flow diagram to support the decision-making process and prevent unnecessary use of antimicrobials in exotic patients. (Adapted from FECAVA Advice on responsible use of antimicrobials. FECAVA working group on hygiene and the use of antimicrobials in veterinary practice. 2014; with permission. Available at: http://www.fecava.org/sites/default/files/files/ 2014_12_fecava_responsible\%20use\%20AM.pdf.) 


\begin{tabular}{|c|c|c|c|}
\hline Antimicrobial Class & Antimicrobial Agents & $\begin{array}{l}\text { Susceptible } \\
\text { Pathogens }\end{array}$ & Resistance \\
\hline $\begin{array}{l}\text { Penicillins } \\
\text { (narrow-spectrum) }\end{array}$ & $\begin{array}{l}\text { Benzylpenicillin, } \\
\text { procaïnepenicillin }\end{array}$ & $\begin{array}{l}\text { Many gram positives; } \\
\text { most anaerobes; } \\
\text { Pasteurellaceae; } \\
\text { Mannheimia spp; } \\
\text { Actinobacillus spp; } \\
\text { Haemophilus spp; } \\
\text { Histophilus spp }\end{array}$ & $\begin{array}{l}\text { Most gram negatives; } \\
\text { mycoplasmata; } \\
\text { methicillin-resistant } \\
\text { staphylococci }\end{array}$ \\
\hline $\begin{array}{l}\text { Penicillins } \\
\text { (broad-spectrum) }\end{array}$ & $\begin{array}{l}\text { Ampicillin, } \\
\text { amoxicillin, } \\
\text { amoxicillin/ } \\
\text { clavulanic acid }\end{array}$ & $\begin{array}{l}\text { See penicillin } \\
\text { (narrow-spectrum); } \\
\text { many gram } \\
\text { negatives }\end{array}$ & $\begin{array}{l}\text { Pseudomonas spp; } \\
\text { Klebsiella spp; } \\
\text { Enterobacter spp; } \\
\text { Citrobacter spp; } \\
\text { Acinetobacter spp; } \\
\text { Yersinia } \\
\text { enterocolitica; } \\
\text { mycoplasmata; } \\
\text { methicillin-resistant } \\
\text { staphylococci }\end{array}$ \\
\hline $\begin{array}{l}\text { Penicillins } \\
\text { (antipseudomonal) }\end{array}$ & $\begin{array}{l}\text { Ticarcillin, }^{a} \\
\text { piperacillin }^{a}\end{array}$ & $\begin{array}{l}\text { See penicillin (broad- } \\
\text { spectrum); } \\
\text { Pseudomonas spp }\end{array}$ & $\begin{array}{l}\text { Mycoplasmata; } \\
\text { methicillin-resistant } \\
\text { staphylococci }\end{array}$ \\
\hline \multirow[t]{2}{*}{ Cephalosporins } & $\begin{array}{l}\text { First-generation } \\
\text { cephalosporins } \\
(e g, \text { cephalexin, } \\
\left.\text { cefazolin }{ }^{a}\right)\end{array}$ & $\begin{array}{l}\text { Many gram positives; } \\
\text { most } \\
\text { Enterobacteriaceae; } \\
\text { most anaerobes; } \\
\text { Pasteurellaceae; } \\
\text { Mannheimia spp; } \\
\text { Haemophilus spp }\end{array}$ & $\begin{array}{l}\text { Enterobacter spp; } \\
\text { Pseudomonas spp; } \\
\text { Citrobacter spp; } \\
\text { Acinetobacter spp; } \\
\text { Y enterocolitica; } \\
\text { methicillin-resistant } \\
\text { staphylococci; } \\
\text { enterococci }\end{array}$ \\
\hline & $\begin{array}{l}\text { Third- and fourth- } \\
\text { generation } \\
\text { cephalosporins } \\
\text { (eg, ceftiofur, } \\
\text { cefquinome, } \\
\text { ceftazidime }^{\text {a) }}\end{array}$ & $\begin{array}{l}\text { See first-generation } \\
\text { cephalosporins; } \\
\text { Pseudomonas spp } \\
\text { (fourth and } \\
\text { ceftazidime) }\end{array}$ & $\begin{array}{l}\text { Some Pseudomonas } \\
\text { spp (third); } \\
\text { methicillin-resistant } \\
\text { staphylococci; } \\
\text { enterococci }\end{array}$ \\
\hline Lincosamides & $\begin{array}{l}\text { Lincomycin, } \\
\text { clindamycin }\end{array}$ & $\begin{array}{l}\text { Gram-positive } \\
\text { aerobes; anaerobes; } \\
\text { mycoplasmata }\end{array}$ & $\begin{array}{l}\text { Gram-negative } \\
\text { aerobes; } \\
\text { enterococci }\end{array}$ \\
\hline Macrolides/azalides & $\begin{array}{l}\text { Erythromycin, } \\
\text { tylosin, spiramycin, } \\
\text { azithromycin }^{a}\end{array}$ & $\begin{array}{l}\text { Many gram positives; } \\
\text { most } \\
\text { mycoplasmata; } \\
\text { Chlamydia spp; } \\
\text { Mycobacterium spp; } \\
\text { Campylobacter spp }\end{array}$ & $\begin{array}{l}\text { Many gram negatives; } \\
\text { enterococci }\end{array}$ \\
\hline Aminoglycosides & $\begin{array}{r}\text { Gentamicin, } \\
\text { neomycin, } \\
\text { amikacin }^{a}\end{array}$ & $\begin{array}{l}\text { Some gram positives; } \\
\text { most gram } \\
\text { negatives }\end{array}$ & $\begin{array}{r}\text { Streptococci; } \\
\text { anaerobes }\end{array}$ \\
\hline
\end{tabular}




\begin{tabular}{|c|c|c|c|}
\hline $\begin{array}{l}\text { Table } 2 \\
\text { (continued) }\end{array}$ & & & \\
\hline Antimicrobial Class & Antimicrobial Agents & $\begin{array}{l}\text { Susceptible } \\
\text { Pathogens }\end{array}$ & Resistance \\
\hline Tetracyclins & $\begin{array}{l}\text { Doxycycline, } \\
\text { tetracycline }\end{array}$ & $\begin{array}{l}\text { Many gram positives; } \\
\text { many gram } \\
\text { negatives; } \\
\text { mycoplasmata; } \\
\text { Chlamydia spp }\end{array}$ & $\begin{array}{l}\text { Pseudomonas spp; } \\
\text { Proteus spp }\end{array}$ \\
\hline Phenicols & $\begin{array}{l}\text { Chloramphenicol, } \\
\text { florfenicol }\end{array}$ & $\begin{array}{l}\text { Many gram positives; } \\
\text { many gram } \\
\text { negatives; } \\
\text { anaerobes; } \\
\text { mycoplasmata; } \\
\text { Chlamydia spp } \\
\end{array}$ & Pseudomonas spp \\
\hline Diaminopyrimidines & Trimethoprim & $\begin{array}{l}\text { Many gram positives; } \\
\text { many gram } \\
\text { negatives }\end{array}$ & $\begin{array}{l}\text { Pseudomonas spp; } \\
\text { anaerobes }\end{array}$ \\
\hline Sulfonamides & $\begin{array}{l}\text { Sulfadiazine, } \\
\text { sulfamethoxazole }\end{array}$ & $\begin{array}{l}\text { Many gram positives; } \\
\text { many gram } \\
\text { negatives }\end{array}$ & Pseudomonas spp \\
\hline Fluoroquinolones & $\begin{array}{l}\text { Enrofloxacin, } \\
\text { marbofloxacin }\end{array}$ & $\begin{array}{l}\text { Most gram negatives; } \\
\text { mycoplasmata; } \\
\text { Chlamydia spp; } \\
\text { Mycobacterium spp; } \\
\text { Campylobacter spp }\end{array}$ & $\begin{array}{l}\text { Less active against } \\
\text { gram positives; } \\
\text { anaerobes }\end{array}$ \\
\hline Nitroimidazoles & Metronidazole & Anaerobes & Aerobes \\
\hline
\end{tabular}

a Authorized for human use only.

into account are the likelihood of the bacterial infection to resolve without the use of antibiotics and the disease severity. Antimicrobials are preferably reserved for those cases where no other options (eg, use of antiseptics) are available and delay of therapy will result in a compromised well-being of the animal.

If the use of antibiotics is deemed appropriate, the selection of a therapy should ideally be based on an accurate diagnosis and antimicrobial susceptibility testing. However, in several situations (eg, seriously ill animal requiring immediate therapy, no representative sample obtainable, no routine susceptibility testing available) empirical therapy is the next best thing. When prescribing antimicrobials based on empiricism, knowledge of the most common pathogens causing certain infections and of antimicrobial spectrum of antimicrobial agents is indispensable. For certain bacteria (eg, $\beta$-hemolytic streptococci, Pasteurellaceae, and Chlamydiaceae) susceptibilities are predictable. Other, mostly gram-negative bacteria rapidly acquire resistance genes, making susceptibility patterns hard to predict. Additional factors to consider when prescribing and selecting antimicrobials are pharmacokinetic and pharmacodynamics properties, potential toxicities or adverse effects, the route of administration, and costs of the selected antimicrobial agent. ${ }^{42}$ To avoid disturbance of the normal gut flora and to minimize selection of antimicrobial resistant organisms, local treatment with antiseptic drugs and narrow-spectrum antimicrobials are preferable to systemic treatment and broad-spectrum antimicrobials, respectively.

Table 2 presents a concise overview of veterinary important antimicrobial agents and their activity against common veterinary pathogens. 


\section{RECOMMENDATIONS}

In exotic animals, evidence-based treatment guidelines for infections, including antimicrobial stewardship considerations, are not yet available. Common practice is based on personal experiences of successful strategies by individual veterinary specialists because of absence of suitable veterinary medicinal products, or on literature aiming at $100 \%$ susceptibility of all suspected pathogens. ${ }^{42}$ This results in frequent (off label) application of antimicrobials categorized as critically important antimicrobials by the WHO, such as fluoroquinolones, aminopenicillins, third-generation cephalosporins, and macrolides. The most important consideration in case of an acute infection in exotic animal should be what pathogen is most likely causing the symptoms, and whether antimicrobial therapy is needed. A list of appropriate antimicrobials is needed for empiric therapy, and consensus on the right dose and preferable length of therapy. For these antimicrobials, adequate pharmaceutical formulations should be developed. Until then, antimicrobial stewardship in exotic animals will be hampered by the unavailability of treatment options.

\section{ACKNOWLEDGMENTS}

We would like to thank Dr. Y.R.A. van Zeeland for proofreading of and valuable contribution to the article.

\section{REFERENCES}

1. World Health Organization. Global action plan on antimicrobial resistance. At the Sixty-Eight World Health Assembly in May 2015. 2015. Available at: http://www. who.int/antimicrobial-resistance/global-action-plan/en/. Accessed December 17, 2017.

2. World Health Organization. WHO guidelines on use of medically important antimicrobials in food-producing animals. Available at: http://apps.who.int/iris/ bitstream/10665/258970/1/9789241550130-eng. pdf?ua=1. Accessed December 17, 2017.

3. European Commission. A European one health action plan against antimicrobial resistance (AMR). 2017. Available at: https://ec.europa.eu/health/amr/sites/amr/ files/amr_action_plan_2017_en.pdf. Accessed December 17, 2017.

4. Weese JS, Giguère S, Guardabassi L, et al. ACVIM consensus statement on therapeutic antimicrobial use in animals and antimicrobial resistance. J Vet Intern Med 2015;29(2):487-98.

5. Johns I. Antimicrobial stewardship in the treatment of equine bacterial infections. Vet J 2017;219:4-5.

6. DANMAP. 1996-2016. Use of antimicrobial agents and occurrence of antimicrobial resistance in bacteria from food animals, food and humans in Denmark. Available at: https://www.danmap.org/Downloads/Reports.aspx. Accessed December 17, 2017.

7. SWEDRES/SVARM. 2000-2016. Consumption of antibiotics and occurrence of antibiotic resistance in Sweden. Available at: http://www.sva.se/en/antibiotika/ svarm-reports. Accessed December 17, 2017.

8. NETHMAP/MARAN. 2012-2017. NethMap: Consumption of antimicrobial agents and antimicrobial resistance among medically important bacteria in the Netherlands/MARAN: Monitoring of antimicrobial resistance and antibiotic usage in animals in the Netherlands in 2016. Available at: http://www.swab.nl/swab/cms3. 
nsf/viewdoc/20BCD3983B5C390AC12575850031D33D. Accessed December 17, 2017.

9. BelVet-SAC. Belgian veterinary surveillance of antibacterial consumption. National consumption report. 2013-2016. Available at: http://www.amcra.be/nl/ rapporten-publicaties-en-wetgeving/nationale-rapporten. Accessed December 17, 2017.

10. Taverne F, Jacobs J, Heederik D, et al. Influence of applying different units of measurement on reporting antimicrobial consumption data for pig farms. BMC Vet Res 2015;11:250, 9.

11. Postma M, Sjölund M, Collineau L, et al. MINAPIG consortium. Assigning defined daily doses animal: a European multi-country experience for antimicrobial products authorized for usage in pigs. J Antimicrob Chemother 2015;70(1):294-302.

12. Grave K, Torren-Edo J, Mackay D. Comparison of the sales of veterinary antibacterial agents between 10 European countries. J Antimicrob Chemother 2010;65: 2037-40.

13. European Medicines Agency. Revised ESVAC reflection paper on collecting data on consumption of antimicrobial agents per animal species, on technical units of measurement and indicators for reporting consumption of antimicrobial agents in animals. 2013. Available at: http://www.ema.europa.eu/docs/en_GB/document_ library/Scientific_guideline/2012/12/WC500136456.pdf. Accessed December 17, 2017.

14. ECDC (European Centre for Disease Prevention and Control), EFSA (European Food Safety Authority), EMA (European Medicines Agency). ECDC/EFSA/EMA second joint report on the integrated analysis of the consumption of antimicrobial agents and occurrence of antimicrobial resistance in bacteria from humans and food-producing animals-Joint Interagency Antimicrobial Consumption and Resistance Analysis (JIACRA) Report. EFSA Journal 2017; 15:4872, 135.

15. Netherlands Veterinary Medicines Institute, Expert panel. Usage of antimicrobial drugs in companion animals $2012-2014$ results of a survey of veterinary practices in the Netherlands. 2017. Available at: http://www.autoriteitdiergeneesmiddelen.nl/ en/publications. Accessed December 17, 2017.

16. European Medicines Agency. Standardised units of measurement for veterinary antimicrobials. 2016. Available at: http://www.ema.europa.eu/ema/index.jsp? curl=pages/regulation/general/general_content_001493.

jsp\&mid=WC0b01ac0580a2fcf5. Accessed December 17, 2017.

17. European Medicines Agency, European Surveillance of Veterinary Antimicrobial Consumption. Sales of veterinary antimicrobial agents in 30 European countries in 2015 (EMA/184855/2017). Available at: http://www.ema.europa.eu/docs/en_ GB/document_library/Report/2017/10/WC500236750.pdf. Accessed December 17, 2017.

18. U.S. Food and Drug Administration FDA. Annual summary report on antimicrobials sold or distributed in 2016 for use in food-producing animals. 2017. Available at: https://www.fda.gov/downloads/Forlndustry/UserFees/AnimalDrugUser FeeActADUFA/UCM588085.pdf. Accessed January 1, 2018.

19. Netherlands Veterinary Medicines Institute, Expert panel. Usage of antibiotics in agricultural livestock in the Netherlands in 2016. Trends and benchmarking of livestock farms and veterinarians. 2017. Available at: http://www. autoriteitdiergeneesmiddelen.nl/Userfiles/Eng\%20rapport\%20AB\%202016/engelsdef-rapportage-2016-deel-1-en-2-22-09-2017.pdf. Accessed December 17, 2017. 
20. Hardefeldt LY, Holloway S, Trott DJ, et al. Antimicrobial prescribing in dogs and cats in Australia: results of the Australasian infectious disease advisory panel survey. J Vet Intern Med 2017;31:1100-7.

21. Pleydell EJ, Souphavanh K, Hill KE, et al. Descriptive epidemiological study of the use of antimicrobial drugs by companion animal veterinarians in New Zealand. N Z Vet J 2012;60:115-22.

22. Murphy CP, Reid-Smith RJ, Boerlin P, et al. Out-patient antimicrobial drug use in dogs and cats for new disease events from community companion animal practices in Ontario. Can Vet J 2012;53(3):291-8.

23. Buckland EL, O'Neill D, Summers J, et al. Characterisation of antimicrobial usage in cats and dogs attending UK primary care companion animal veterinary practices. Vet Rec 2016;179:489.

24. Guardabassi L, Prescott JF. Antimicrobial stewardship in small animal veterinary practice: from theory to practice. Vet Clin North Am Small Anim Pract 2015;45: 361-76.

25. Divers SJ, Sladakovic I, Mayer J, et al. Development of an antibiotic policy in a zoological medicine service and approach to antibiotic dosing using mic data. In: 3rd International Conference on Avian herpetological and Exotic mammal medicine PROCEEDINGS 2017. Available at: https://distribuzione.evsrl.it/ ArticleDetail.aspx?lang=en\&from=HP\&id=4822. Accessed December 17, 2017.

26. Briscoe JA, Morris DO, Rankin SC, et al. Methicillin-resistant Staphylococcus aureus-associated dermatitis in a Congo African grey parrot (Psittacus erithacus erithacus). J Avian Med Surg 2008;22:336-43.

27. Loncaric I, Künzel F. Sequence type 398 methicillin-resistant Staphylococcus aureus infection in a pet rabbit. Vet Dermatol 2013;24:370-2.

28. Sousa M, Silva N, Igrejas G, et al. Genetic diversity and antibiotic resistance among coagulase-negative staphylococci recovered from birds of prey in Portugal. Microb Drug Resist 2016;22:727-30.

29. Yilmaz ES, Dolar A. Detection of extended-spectrum $\beta$-lactamases in Escherichia coli from cage birds. J Exotic Pet Med 2017;26:13-8.

30. Cortés-Cortés G, Lozano-Zarain P, Torres C, et al. Detection and molecular characterization of Escherichia coli strains producers of extended-spectrum and CMY-2 type beta-lactamases, isolated from turtles in Mexico. Vector Borne Zoonotic Dis 2016;16:595-603.

31. World Health Organization. Critically important antimicrobials for human medicine. 5th revision. 2017. Available at: http://www.who.int/foodsafety/publications/ antimicrobials-fifth/en/. Accessed December 17, 2017.

32. European Commission. Commission Notice. Guidelines for the prudent use of antimicrobials in veterinary medicine. Official Journal of the European Union 2015; C 299/04. Available at: https://ec.europa.eu/health/sites/health/files/antimicrobial_ resistance/docs/2015_prudent_use_guidelines_en.pdf. Accessed December 17, 2017.

33. Werkgroep Veterinair Antibiotica Beleid (Working Party for Policy on Veterinary Antimicrobials). WVAB -richtlijn classificatie van veterinaire antimicrobiële middeIen. Available at: http://wvab.knmvd.nl/media/default.aspx/emma/org/10886458/ 170201\%20wvab\%20richtlijn\%203.2\%20definitief.pdf. Accessed December 17, 2017.

34. Anonymus (Dutch legislation). Besluit Diergeneeskundigen art 5.7 Gevoeligheidsbepaling bij toepassing aangewezen diergeneesmiddelen. Available at: http://wetten.overheid.nl/jci1.3:c:BWBR0035091\&hoofdstuk=5\&artikel=5.7\&z= 2016-09-01\&g=2016-09-01. Accessed December 17, 2017. 
35. Anonymus (Dutch legislation). Regeling Diergeneeskundigen art. 5.8 Gevoeligheidsbepaling bij toepassing aangewezen diergeneesmiddelen. Available at: http://wetten.overheid.nl/jci1.3: c:BWBR0035238\&hoofdstuk=5\&paragraaf =2\& artikel=5.8\&z=2017-01-01\&g=2017-01-01. Accessed December 17, 2017.

36. Netherlands Veterinary Medicines Institute, Expert panel. Association between antimicrobial use and the prevalence of resistant micro-organisms. SDa-report. 2016. Available at: http://www.autoriteitdiergeneesmiddelen.nl/en/publications. Accessed December 17, 2017.

37. ECDC (European Centre for Disease Prevention and Control), EFSA (European Food Safety Authority), EMA (European Medicines Agency). ECDC/EFSA/EMA first joint report on the integrated analysis of the consumption of antimicrobial agents and occurrence of antimicrobial resistance in bacteria from humans and food producing animals. Stockholm/Parma/London: ECDC/EFSA/EMA, 2015. EFSA Journal 2015;13:4006, 114.

38. Tang KL, Caffrey NP, Nóbrega DB, et al. Restricting the use of antibiotics in foodproducing animals and its associations with antibiotic resistance in foodproducing animals and human beings: a systematic review and meta-analysis. Lancet Planet Health 2017;1:e316-27.

39. McGowan JE Jr, Gerding DN. Does antibiotic prevent resistance? New Horiz 1996;4:370-6.

40. Dyar OJ, Huttner B, Schouten J, et al. ESGAP (ESCMID Study Group for Antimicrobial stewardshiP). What is antimicrobial stewardship? Clin Microbiol Infect 2017;23:793-8.

41. Narver HL. Antimicrobial stewardship in laboratory animal facilities. J Am Assoc Lab Anim Sci 2017;56:6-10.

42. Weese JS, Page SW, Prescott JF. Antimicrobial stewardship in animals. In: Giguère S, Prescott J, Dowling PM, editors. Antimicrobial therapy in veterinary medicine. Hoboken (NJ): John Wiley and Sons; 2013. p. 117-32.

43. Padovan J, Ralić J, Letfus $V$, et al. Investigating the barriers to bioavailability of macrolide antibiotics in the rat. Eur J Drug Metab Pharmacokinet 2012;37: 163-71.

44. Rougier S, Galland D, Boucher S, et al. Epidemiology and susceptibility of pathogenic bacteria responsible for upper respiratory tract infections in pet rabbits. Vet Microbiol 2006;115:192-8.

45. Minarikova A, Hauptman K, Knotek Z, et al. Microbial flora of odontogenic abscesses in pet guinea pigs. Vet Rec 2016;179:331, 4.

46. Watson MK, Wittenburg LA, Bui CT, et al. Pharmacokinetics and bioavailability of orbifloxacin oral suspension in New Zealand white rabbits (Oryctolagus cuniculus). Am J Vet Res 2015;76:946-51.

47. Marín P, García-Martínez F, Hernándis V, et al. Pharmacokinetics of norfloxacin after intravenous, intramuscular and subcutaneous administration to rabbits. J Vet Pharmacol Ther 2018;41:137-41.

48. Abo-el-Sooud K, Goudah A. Influence of pasteurella multocida infection on the pharmacokinetic behavior of marbofloxacin after intravenous and intramuscular administrations in rabbits. J Vet Pharmacol Ther 2010;33:63-8. 